\title{
Budgetjam! A communications intervention in the political- economic crisis in Ireland
}

\section{Gavan Titley}

National University of Ir eland, Maynooth, Ireland

\begin{abstract}
This essay reflects on a communications intervention organized immediately following the 'bailout' provided to Ireland by the troika of the European Commission, the International Monetary Fund (IMF) and the European Central Bank (ECB), and preceding the implementation of an 'austerity' budget designed to further the transfer of banking debt to the sovereign. Reacting to the steadfast official narrative that there is no alternative', and the general failure of mainstream journalism to question the framing of the 'bailout', a network of political and community activists, journalists and academics experimented with ways of challenging the dominant framing of the crisis.
\end{abstract}

\section{Keywords}

Austerity, Europe, financial journalism, Ireland, jamming, neoliberalism

\section{Introduction}

The global financial crisis has given rise to a range of critical questions for the genre of financial journalism (Schechter, 2012: Tambini, 2008, 2010), and more generally for journalism's capacities to map and represent complex global processes within which an acutely reflexive role is thrust upon journalists, and where reporting may have a performative impact (Hind, 2010). The communications project discussed in this essay proceeded from a more basic critical insight: the marginal importance accorded to social experience and societal concerns in the reporting and mediation of political-economic crisis in Ireland during 2010. Alain Badiou (2010) provides an extended metaphor adequate to this context. The crisis, according to Badiou, has unfolded with the narrative conformity of a conventional disaster movie, from the "gradual spectacle of the disaster,

Corresponding auth or:

Gavan Titley, School of English, Media and Theatre Studies, National University of Ireland, Maynooth, Ireland.

Email: gavan.ritley@nuim.ie 
and the crude manipulation of suspense' to the resolute appearance on the screen of the 'little squad of the powerful'. The central focus on rescuing the banking system, and imposing 'deficit-reduction' measures aimed at restoring investor confidence, take on the quality of a 'noble, humanist and democratic' mission, evangelized by mainstream politicians and media. Where, in this crisis, is the real, and where is the spectacle? For the most part, Badiou argues, the audience for this blockbuster, a population who will ultimately finance it:

... watch the astronomical figures go by, and automatically compare them with their own resources, and, in the case of a sizeable proportion of humanity, the complete lack of resources that makes the last years of their lives both so bitter and so brave. I am telling you: that is the real, and we will gain access to it only if we take our eyes off the screen and look at the invisible masses of those for whom, until just before they were plunged into something even worse than what they had already experienced, the disaster movie and its schmaltzy ending was never anything more than a shadow play. (2010:93-94)

Badiou's polemical metaphor is of precise relevance to Ireland. The 'little squad of the powerful' came to Dublin in 2010, and the silent, if not passive, audience watched the particular, Irish iteration of the global crisis enter a new chapter under IMF/EU suzerainty. In the period since the Irish government's historically unprecedented decision, in 2008 , to offer a blanket guarantee on deposits and bonds in six banks, a series of scheduled and supplementary austerity budgets had failed to convince 'market analysts' that the Irish state could afford what had become an absurdist spiral of bank recapitalizations, each heralded, in turn, as definitively the last action required (Slattery, 2010). As interest rates on Irish bond yields rose unsustainably, the European Central Bank and the European Commission pressurized the Irish state into accepting a 'bailout' in the overall interests of the Eurozone (and at a punitive interest rate of $5.7 \%$, pour encourager les autres). ${ }^{1}$

Having offered a blind guarantee for at least $€ 44$ billion of bank debt, thus underwriting what have been revealed to be fundamentally corrupt and mismanaged banks, the government exposed the state to the possibility of sovereign, public default in the event of a private bank 'credit event' ${ }^{2}$ To remedy this, a period of post-sovereignty, which consolidated the transfer of vast sums of private debt to the public in Ireland, was implemented. The EU-IMF loan agreement, signed in late November 2010, involved the transfer of $€ 17.5$ billion from the National Pension Reserve and other funds to the international loan fund, and was structured through a series of coercive 'policy conditionalities' specifying spending cuts, tax rises and privatizations (Storey, 2010). While post-sovereignty was greeted as a form of national shame, it quickly became a malleable political alibi, as was made very clear in the 2010 'austerity' budget, a week after the loan agreement was signed.

Leaving aside the substance of the budget momentarily, it is worth considering it as an anthropological, or at least communicative event. The budget was invested with totemic significance, sending signals to a variety of capitalist agencies that required convincing as to not just the 'fiscal rectitude' but also the consoling character of society in Ireland. Thus the implementation of 'austerity', with its 'connotations of admirably severe virtue' (Poole, 2011), did not so much describe an ideological decision to redistribute wealth to proven wealth-destroyers as suggest a moral project, an emetic 
for a nation that had 'gotten ahead of itself'. Similarly, while, as Larry Elliot (2010) argued at the time, an insistence on extraordinarily savage budget cuts - designed to shrink the budget deficit from 14 per cent to 3 per cent by 2014 - were more likely to lead to depression than 'growth' (as we are now witnessing), ${ }^{3}$ no price could be placed on their semiotic value, as a 'sign that we are on the road to recovery' by 'restoring confidence'.

Where there are totems, there are also taboos. When an event is invested with this degree of (imagined) communicative significance, then dissent is taboo, as it also sends out signals: it dents 'confidence'; provides premonitions of social unrest and attendant investor uncertainty; and risks, as many commentators pointed out, Ireland looking like Greece. ${ }^{4}$ Public discourse, in the main, played out like an appendix to Barbara Ehrenreich's Smile or Die (2009); insisting that, while people had the 'right' to be angry, that we needed to move on, reject a negativity that could have no impact on 'reality', and embrace positivity 'going forward'. Essentialized recourse to the 'national character' enjoyed a political resurgence, with the then-Finance Minister Brian Lenihan declaring that 'The steps taken have amazed our partners in Europe, who are amazed at our capacity to take pain. In France, you would have riots if you tried to do this' (Finn, 2011). While the government's political discourse poured scorn on those who questioned the idea that there was no alternative to this particular form of settlement, the range of admissible, mainstream media opinion was also deeply restricted. What Eric Louw calls the 'sensible centre' of political journalism (2005: 76) was deeply influenced by the truistic idea that 'we are where we are', spending considerably more effort, for example, on reading the runes of IMF-EU statements for reassuring signals of recovery than, for example, detailing the empirical impacts of IMF conditionalities on other non-European, debtor societies (see Storey, 2010).

Such sweeping generalizations of media activity are, of course, out of place in a social scientific investigation. However, this essay is written as a reconstruction of an activist project, ${ }^{5}$ and its focus is on the rationale of the intervention at a particular moment in time, and on providing a critical assessment in retrospect. Significant empirical research into media coverage and media-political dynamics during this period in Ireland is certainly required. For now, this essay reflects our assessment of the general dominance of what Dan Hind has called a 'hallucinatory system of descriptions and a chain of pretended necessities that is only plausible in the absence of accurate information' (2010: 12). It was as a reaction to this hallucination, to the structure of moralized politics and cultural mythology sutured to the political-economic violence of austerity, that the communications collective Budgetjam was formed.

\section{We all partied: Ireland does crisis}

In the emerging literature on the global economic crisis, there is a widespread recognition that 2008-9 presented the potential for a paradigmatic break, the "beginning of an actual public conversation about the nature of debt, of money, of the financial institutions that have come to hold the fate of nations in their grip' (Graeber, 2011a: 15). Of course, as Graeber points out, ' $\ldots$ that was just a moment. The conversation never ended up taking place. ${ }^{6}$ What Graeber describes as the 'colossal lie' of 'preternaturally capable' financial 
innovations is one answer to the rhetorical questions posed by Colin Crouch, in the introduction to his aptly titled The Strange Non-Death of Neoliberalism:

The financial collapse challenged these ideas (of the efficient functioning of deregulated markets) because it involved the world's leading banks. They are profit-maximizers, acting in the purest of markets; how can they possibly not have contributed to the sum of human welfare in all that they did? How could it be that today's financial markets, the most sophisticated form of the market probably in human history, could run into trouble of such a massive kind, when the most advanced economic theory had demonstrated that unregulated financial markets will be self-correcting? (2011: vii)

In Crouch's analysis, the potential of this great public conversation was in part stymied by the terms in which it was conducted: 'actually existing, as opposed to ideologically pure' neoliberalism is not opposed to state intervention, nor wedded, in practice, to 'free markets', rather 'it is devoted to the dominance of public life by the giant corporation' (2011:vii). In a historically informed analysis of neoliberal ism as a rationality characterized by the interplay of ideological certitude and contextual opportunism, Jamie Peck presents this gap, between the 'pristine clarity of the ideological apparition (of) the free market' and repeated empirical failure, as a dialectic that informs a tendency to '... "fail forward", in that their manifest inadequacies have - so far anyway - repeatedly animated further rounds of neoliberal animation' (2011: 6, italics in original). Thus in another study which opens with reference to the ephemeral discursive challenge to the orthodoxy in 2008, David McNally (2011) frames it as a hiatus that in fact prepared the ground for the further capture of the state. What he terms the 'neoliberal mutation' - the rapid discursive shift away from the systemic weaknesses of finance capitalism to the ideological 'necessity' of slashing state investment and spending - involves a longer-term project to transform the modern state, and its relationship to society.

The bleak condition of mainstream public discourse in Ireland is perhaps best captured by the fact that this fleeting conversation never developed, even as the mutation mutated in plain sight. This lack of critical mobilization must be regarded as a product of the collective failure of media, academia and NGOs to pursue adequately critical questions during the preceding decade of credit-fuelled growth. As several accounts have emphasized, the economic 'boom' baptized as the 'Celtic Tiger' was in serious trouble long before the global financial crisis, yet the difference between its two relatively distinct phases of economic activity was masked by a triumphalist cultural narrative of national arrival (Kirby et al., 2002). The primarily US-derived foreign direct investment growth (FDI) of the 1990s diminished after the US recession of 2001, only to be replaced with ' $\ldots$ a new emphasis on construction and finance generating a property bubble with few parallels in modern economic history' (Finn, 2011). As Denis O'Hearn summarizes:

Economic disaster hit Ireland as quickly as success. Yet they should have seen it coming. FDI began falling at the turn of the century and the stock of FDI fell from 130 percent of GDP in 2001 to 67 percent by 2006 . Yet some Irish economists preferred to see this as a sign of Irish economic maturity: economic growth continued at a respectable pace as the motor of growth shifted from foreign industry to construction. Few considered whether the construction sector was sustainable. Money that had been accumulated during the years of the Celtic Tiger, partly 
as the result of the government's policy of favouring large tax cuts for the wealthy rather than provision of social services, sought an outlet for profitable investment and found one for a few years in construction. (2011:2-3)

The widespread tendency of domestic and international commentators to discuss the Irish 'miracle' in modular terms, as comprising an economic template that could be replicated elsewhere through low taxation, corporate-friendly regulation and a flexible labour market (Finn, 2011; O'Hearn, 2011) blended with a dominant narrative of cultural arrival. Regularly contrasted with a reductive tableau of a conflictual, repressive and impoverished 'past', this economic boosterism was mirrored in a popular culture determined to fix Irishness as a collectivized maturity, with a veneer of global cool legitimated by the fleeting cultural capital accorded by this international attention. The popular psychologist Maureen Gaffney provides a synthesizing example of this tendency:

We seem to have used our prosperity as an opportunity to enjoy stable family relationships, to develop our personal expressiveness and to show the world what we're good at. Given Ireland's economic, cultural and religious history - still in living memory - we have embraced prosperity, the good life and personal freedoms with unabashed relish, and we won't lightly let them go. (2007: 68)

This unabashed relish has given way to a bashfulness that is as evasive as it is reflective. Nevertheless, the general lack of critical investigation and public comment among economists and social scientists has become a subject of much debate, ${ }^{7}$ and a nascent reflection is also being conducted in the mainstream media. In the assessment of the former editor of The Irish Times, Conor Brady, while journalists in Ireland had done much to focus scrutiny on the actions of the banks and the causes of the banking crisis, the laxity of financial regulation and the 'capture' of the financial regulator by vested interests went relatively unexplored, a failure amplified by the 'wild west of European finance' being the focus of several high-profile investigations in the international press. ${ }^{8}$ According to Brady:

... it is evident now that many people in key positions were aware over time that there were serious systemic issues in the business and economic sectors. Yet this did not make its way into the mainstream news media in a form that was sufficiently sustained, coherent and authoritative. (2010)

In the first study to be conducted on financial journalism in Ireland in the context of crisis, Fahy et al. (2010) interviewed financial journalists to examine their reflections on their collective performance during the 'Celtic Tiger' period. Reflecting comparative international studies (Tambini, 2008), some journalists pointed to the implicit pressures of maintaining source access, and a dependence on the (limited) information provided by financial institutions. Some noted that critical voices could be effectively excluded from elite networks of information-sharing, as well as facing significant criticism - and some abuse - in the public sphere for 'talking down the economy'. ${ }^{9}$ In investigating a line that has been widely assumed in public debate, the financial importance of property advertising to media outlets was noted by several journalists. One contended that this led to an easy acceptance of the veracity of information provided by the banks concerning their 
commercial property lending, and also, according to another respondent, a belief that journalists were "leaned on by their organisations not to talk down the banks (and the) property market because these organisations had a heavy reliance on property advertising' (Fahy et al., 2010: 15). As they conclude:

... the responses indicated that the tendency for financial journalists to operate with in elite-elite networks was more pronounced during the Celtic Tiger years, as the lack of criticism from regulatory, economic or policy sources contributed to the lack of sustained criticism in news coverage. This tension was intensified by the fact that the wider financial system in which they have been embedded conceptualized their role so narrowly, and has frequently made access to information so difficult, thereby making systemic criticism more difficult. (2010:18)

Systemic critique was also muted among NGOs and mainstream civil society organizations, and it is in this specific context that the Budgetjam network was formed. The critical inadequacy of the public sphere had been a central theme at a seminar I co-organized in May 2010, as part of Goldsmith's Leverhulme Media Research Centre and the Carnegie Trust UK's project 'Protecting the News: Civil Society and the Media'. Departing from a normative commitment to enhancing citizen participation in 'thoroughly mediated democracies', the project emphasized the new communicative spaces and digital possibilities available to civil society organizations, with particular emphasis on providing a diversity of viewpoints and sources in the face of the general homogenization of mainstream news content (Witschge et al., 2010).

However, as the broader Carnegie inquiry into the future of civil society had observed, the 20-year history of 'social partnership' - a corporatist employment and social policy structure between government, employers, trade unions and civil society organizations (see Larragy, 2006, for a overview) - had done significant damage to the capacity of NGOs and many civil society actors to act with political independence. It created a hierarchy of those within and outwith the pillars of Partnership; redirected campaigning skills to lobbying activities; and left issue-based NGOs vulnerable to funding threats on sensitive social issues which threatened to bring them into conflict with state prerogatives. When Partnership collapsed in 2009, it was widely held that the NGO sector would need to re-learn to act politically, and to communicate in a political environment where hostility to what were now termed 'vested interests' was a corollary of a particular understanding of the 'national interest'. In this context, our research group organized an event in May 2010, 'Media and civil society in crisis', and this gathering of journalists and bloggers, researchers and activists, and (formerly) state-funded and autonomous organizations and movements provided the network for Budgetjam's subsequent 'communications intervention'.

\section{They're securing the future by abolishing it: A week of jamming}

In a series of meetings in the six weeks preceding the December 2010 budget, we brought together a diverse network of activists to think about what a communications intervention could do, and how. The project was coordinated by a core group of roughly 15 people, 
with a further circle of $30-40$ people regularly involved, and finally a contributing network of over 100 people. If I were to categorize those involved - at best a very inexact practice given how many people inhabit more than one of these categories - the extended group involved (a) activists from left political parties, (b) activists from autonomous and community-based networks and organizations, (c) academics and researchers in political economy, development politics, sociology, media and journalism, education, history, (d) mainstream media journalists and influential left bloggers, and (e) trade unionists.

The task of building such a political network involves confronting the extent to which analytical and ideological agreement is necessary for political mobilization. In this preOccupy action, we were very clear that we were looking to build some form of contingent political intervention from scratch, and thus to create a new and necessarily loose network that did not attempt to define or restrict the nature of anybody's political participation, or input. This extended to our media practice; as one participant commented afterwards, we built a 'neutral movement space' that could not be mistaken as a Front or Trojan horse for any one party or set of interests, and precisely because of this, it benefitted from a certain sense of freedom to participate and play; with language, images, strategies and forms. ${ }^{10}$ This was also pragmatic: a commitment to the idea that whosoever is involved are the right people to be involved allows active solidarity to be built, particularly under time and resource constraints.

Equally as importantly, the unity of the intervention was forged by a shared sense that the thick weave of neoliberal rationality ${ }^{11}$ that defined public discourse in Ireland required sustained engagement. The aim was not to foreground any one particular analysis or solution, but to unsettle the prevailing sense that no other forms of analysis had any real purchase. While the political energies of people in the network spanned the spectrum of fronts on which 'austerity' was being implemented - cuts to the minimum wage and to social welfare, to spending on special needs education, to the health budget, and so forth - there was a collective awareness that the 'neoliberal mutation' also involved mutations in meaning, the contamination ${ }^{12}$ of putatively progressive vocabularies by reductive and instrumental rationalities (Brown, 2005). Thus the cycle of austerity budgets were implemented under the sign of a natural, cyclical inevitability, but also in the name of 'fairness' - contaminating the space of equality, and justice - and in the name of the collective, 'we're all in this together'.

Nick Couldry, inhis book Why Voice Matters, makes acase for opposing 'neoliberalism's strategy of simplification' with a contrary clarity of purpose, and the following quotation captures quite precisely the consensus emergent from those discussions:

[ ... ] the point of hegemonic terms is to convince us to treat, as similar, things that are very different; that is why such strategies must be opposed, by name, in a reverse strategy of simplification ... Resisting the hegemony of 'neoliberalism' means identifying it as a bounded discourse, a 'term' - in the double sense of word and limit - whose limitations we can think and live beyond. (2010: 6)

If neoliberalism is a 'bounded discourse', how are its limits marked and named, as a necessary condition of unsettling and perhaps, as Couldry suggests, transcending them? What if, for a sustained period of one week, we could combine the communicative power of a range of actors - blogs, columns, websites, lectures, speeches, 
newsletters, meetings, media appearances, conversations, postings - and direct them all towards a sustained, critical intervention, towards a marking and a fraying of those boundaries? Of course, any oppositional political project formed primarily through communications must of necessity recognize and work through its limitations. Jodi Dean has argued that 'democracy that speaks without listening' incorporates vast quantities of oppositional and critical communication by converting 'messages' into 'contributions'. In other words, in deliberative theories of democratic communication, a message has a use value, where 'understanding is a necessary part of the communicative exchange'. Under what she terms 'communicative capitalism', messages are instead defined by their exchange value, by their 'contribution to a larger pool, flow or circulation of content' (2009: 27-29).

The political justifications for further cuts to living standards and essential services, in our evaluation, were based on the circulation of myths calibrated to the defining form of most mediated debate. More importantly, they were tasked with filling and killing this fraught time-period with media flow; the period between the announcement of the 'bailout' and the austerity budget was one of democracy speaking incessantly, while being explicitly prohibited by external agencies from listening. Accepting Dean's line of critique does not necessitate relinquishing any form of communicative politics; rather it suggests that communicative strategies need to be forged in and sharpened through this awareness. Further, it has contextual aspects; Ireland is a small country, where relatively intimate networks of government and state public relations officers, and political correspondents, shape a news agenda that is slowly shifting in content and process through the digital networking of the news environment. Thus the network set itself the concerted task, for one week leading up to the budget debate in Dáil Éireann (the parliament in Ireland) on 7 December 2010, of contesting and 'jamming' the near-hegemonic circulation of supposedly incontrovertible facts and truths by mainstream media and politicians. We identified five key mantras structuring budget coverage, namely:

1 The country is broke (bankrupt)

2 We're all in this together

3 We have to move on, going forward

4 The tough love of the IMF/EU is actually good after a period of 'mismanagement'

5 (the Ur-mantra) There is no alternative.

We developed three intersecting strategies of tracking and contesting these invitations to passivity:

(a) Each myth was allocated to a working group who produced and gathered informative and accessible critiques which could be disseminated through our website ${ }^{13}$ and social media platforms. The aim here was to circulate factual resources that activist networks could use to challenge the presentation of the 'bailout' deal and its conditionalities. Some examples may illustrate the point. The working group on the IMF, for example, produced and collated information on the failures and corrosive impacts of the IMF's faith in 'expansionary austerity' programmes in the majority world, as well as analyses of the probable future impacts of the policies on public goods and social cohesion. The widely circulated statement by the head of the IMF mission, Ajai Chopra, that the IMF does not 
intervene in the democratic process of debtor countries was easily refuted; Chopra himself, when head of the 'rescue mission' to South Korea in 1997, was party to the IMF interference in the Korean presidential elections, where the delegation refused to release the funds until the four leading candidates had committed to the terms of the 'bailout' (Storey, 2010). Similarly, while Argentina's default in 2002 was consistently held up as a scenario that Ireland must avoid at all costs, the group detailed the consistent errors in IMF growth projections for Argentina in the years prior to and following the default, and laid out informed scenarios for different kinds of default (op.cit.).

The working group on wealth - 'the country is broke' - developed briefings on Ireland's 12.5 per cent corporate tax rate, which was held up as the defining factor in foreign direct investment, and a rate that could not be increased, regardless of the budgetary situation, without causing catastrophic disinvestment, increased unemployment, and future disincentives. The corporate tax rate, particularly when subject to opportunistic attention from the French government, was also subject to nationalist mystification, regularly referred to possessively, as 'our' rate, in news bulletins. As it turns out, research conducted with the large multinational firms indicated that the tax rate was a secondary concern behind access to a young, educated workforce, and governmental involvement in infrastructural planning and provision (Burke, 2011). And so forth; the over-arching point was that significant quantities of research existed that pointed to very different ways of understanding and responding to the political-economic crisis, and this research could also be pared down into a set of claims adequate to mediated debate. These analyses and articles were organized on the website according to the key myths, so that clicking on each myth provided a developing repository of material.

(b) With the informational structure in place, the sense of a cumulative communications event was organized around a liveblog that was maintained from 8a.m. to $10 \mathrm{p} . \mathrm{m}$. every day for six days. People blogged on their own or in pairs, but always as the nodal point for a wider network tasked with monitoring press conferences and the main radio and television politics shows, capturing the contentious aspects of debates or the appearance of the key mythologies, and emailing ready points of analysis to the live-blogger. Crucially, the work of the wider network involved driving traffic and debate to the liveblog, particularly by using Twitter. Twitter has enjoyed an upsurge in use in Ireland, and while most politicians and journalists have accounts, there is, as one journalist in The Irish Times put it delicately, not yet a real 'dialogical expectation' in how it is used. ${ }^{14}$ Thus the network used Twitter to push questions and rebuttals, to circulate the counter-analyses and fact sheets and the contact details of particular media shows and politicians, and to incessantly question the terms of debates. It is perhaps an indication of the success of this particular strategy that \#budgetiam trended consistently in Ireland during this week, and became associated with critical debates about the budget far beyond our network.

(c) While the liveblog developed a sizeable following, the strategy of a flow of sharp and often acerbic comment was also designed to attract attention to the counter-flow of proposals and protests emanating from civil society and activist networks. As the week progressed, the liveblog became a site for coordinating protest actions and for engaging in developing those counter-proposals the left is frequently accused of lacking. Thus, for example, it hosted discussions and analysis of growth-focused 'people's budgets' 
developed by trade union economists and independent, progressive economics networks. Concomitantly, the liveblog was motivated by a focus on Badiou's 'silent audience'; on gathering testimonies and evidence of the social and personal impacts of 'austerity', and of insisting on the irreducibly human dimension traduced and patronized by technocratic declarations that while one's pain may be felt, there is no alternative.

\section{Conclusion: The limits of the 'event'}

This essay has reflected on a specific communications intervention, and the reflection first took shape in the specific context of a symposium of citizenship and journalistic practice. ${ }^{15}$ In conclusion I maintain this contextual focus, which initially involves reflecting on this intervention in terms of journalistic and media practice. When first asked to reflect on the intervention in these terms, I realized that it was not framed or discussed, by those involved, in terms of 'citizen journalism' or 'alternative media', or any other such loose paradigm. In aiming to harness communicative power, Budgetjam was interested simply in amplifying its scale of action within and across networks. In retrospect, it could be theorized in a number of ways. By drawing on the idea of jamming; integrating a variety of established networks to produce participatory journal ism; creating a live, interactive event; and working to mobilize 'politics on the streets', it unr eflectively combined the possibilities of what Leah Lievrouw terms 'genres of contemporary new media projects that have adopted an explicitly alternative, activist or oppositional perspective' (2011:6).

That said, it centrally involved journalists who saw their involvement as part of a countervailing engagement with media failures during the crisis. This countervailing action was understood as such within a discourse of professional journalistic practice; it did not require recourse to any 'alternative' paradigms in order to ground it. Similarly, its reach was accelerated and extended by being hosted by politico.ie, one of the popular, commercial online news sites that have capitalized on the somewhat tentative and sluggish multi-platform strategies of established mainstream media in Ireland. Given that our research and analysis found its way, attributed and unattributed, into press pieces during the week, and that several invitations to contribute to the television and radio shows we were critiquing were forthcoming, the mainstream media had no problems either with a porous border to the supposedly 'alternative'. Thus, it is far more accurate to regard this as an instance of 'networked journalism' (Russell, 2011), where actors in various publics and networks produce journalism material that links, intersects and mixes, while noting that a discussion concerning the distribution of power, recognition and forms of credibility within these publics and networks is only beginning in Ireland.

However, it is worth framing the intervention as 'citizen journalism' to underline that the role of citizen journalism in monitoring, critiquing and holding financial journalism - and more generally, reporting of the 'reality' of the crisis - to account is relatively under explored. Budgetjam assembled alternative budget calculations, assessments of social cost, information on the IMF and the anti-growth consequences of austerity to provide a repository of material that contradicted the dominant official narrative. Beyond this project, social media networking, particularly Twitter, has been consistently used by bloggers, activists and the generally enraged to circulate and draw attention to 
lacunae and problems with official data, as well as to monitor and critique frames of reporting. During the Irish political-economic crisis, several bloggers, most notably TheStory.ie, have played an important role in utilizing freedom of information requests to analyse bank documents and the actions of state bodies such as the National Asset Management Agency (NAMA), established to dispose of the commercial property development loan assets acquired by the state from the banks. ${ }^{16}$ A network of critically oriented blogs engage in regular, specific monitoring and analysis of the politicaleconomic coverage of the public service broadcaster, RTÉ, and the paper of record, The Irish Times, drawing attention to selective interpretations or the absence of alternative, plausible readings of the same data or information. ${ }^{17}$ This critical interplay, and the extent of such activity across the political spectrum in Ireland, requires proper future research.

In terms of the form of this intervention, however, this is not the last word on the politics of information. In his essay on 'Power after hegemony', Scott Lash argues that countervailing analysis can '.. find its ethical moment inside the factual itself. Posthegemonic politics is a politics not of normativity but of such facticity' (2007: 65). Lash's argument maps onto one of the prime drivers of the intervention; the desire to repudiate the recurring refrain that the 'left' can only offer normative positions, and to contend that the politics of 'there is no alternative' is not just built on a failure of imagination, but also of analysis, of facticity. However, in communicative terms, this strays perilously close to rationalist fallacy, conjuring up Habermasian assumptions ${ }^{18}$ within an intervention shaped by post-deliberative conditions: the tenacious circulation of 'key mythologies', and their role in a 'democracy that speaks without listening' (Dean: 2009: 17). To return to Dean's terms, ultimately the 'use value' of the intervention was as much its form as its content. The time-bound, unfolding media event structure allowed for the intensive insinuation of critical perspectives into key sites of public discourse. This of course, demands a concentration of energy and resources that is not easily sustained, or replicated, and which thus demands the constant reworking of communicative strategies that - as was chalked pessimistically on the planning board at one stage 'make them work hard for their eventual victory'. ${ }^{19}$

\section{Notes}

1. As Dan Finn described it, in a New Left Review article on the Irish economic collapse: 'Once the bank guarantee was put in place, the overriding goal of Cowen's government was to shore up the private financial system at any cost. Finance Minister Brian Lenihan initially bragged that Ireland had instituted the "cheapest bailout in the world". As the rotten foundations of Irish banking gradually came into public view, the anticipated cost of the guarantee rose exponentially: realistic estimates at present lie somewhere between $€ 50$ and $€ 70$ billion (Irish GDP in 2008 was a little over $€ 200$ billion). Cowen and Lenihan spurned opportunities to terminate the 2008 guarantee, despite the fact that they had the legal option to do so on the grounds that three of the banks had withheld material information about their solvency, in direct breach of the 1971 Central Bank Act. But, as the economist Morgan Kelly noted, that would have entailed an "unpleasant showdown with the European Central Bank". Instead, "the German and French banks whose solvency is the overriding concern of the ECB get their money back", while "the senior management of the banks that caused this crisis continue to enjoy their richly earned 
rewards. The only difficulty is that the Government's open-ended commitment to cover the bank losses far exceeds the fiscal capacity of the Irish State."' (Finn, 2011).

2. Arguably the most authoritative documenting of the facts and figures of the banking crisis can be found on the blog Namawinelake http://namawinelake.wordpress.com, and, concerning the costs of austerity, on that of UNITE trade union economist Michael Taft: http://notesonthefront.typepad.com/

3. For a discussion of the manifest failure of austerity politics on its own terms see Kinsella (2011), and, for commentary, O'Brennan and Titley (2011).

4. A reflex returned by Greek protestors at the Acropolis in February 2011, where a prominent banner read 'We are not Irish. We will resist.'

5. This essay was first delivered as a paper at a symposium on 'Citizenship and Journalistic Practice' organized by Bolette Blaagaard and Eugene McLaughlin at the Centre for Law, Justice and Journalism in City University, London, on 15 September 2011.

6. The Occupy movement, in Graeber's analysis, has not only stimulated that conversation but drawn attention to the terms on which it is and can be conducted (see 2011b).

7. In international terms, Michael Lewis's 2011 Vanity Fair article drew attention to the status of Prof. Morgan Kelly, who first came to attention when the then-Taoiseach Bertie Ahern indirectly invited him, in 2007, to 'commit suicide'rather than talk down the economy. Kelly's Irish Times articles predicting the economic crash have become popular reference points, and his status both draws attention to a general conformity of mainstream opinion while detracting attention from a wider range of analyses which were never systematically reported. At the time of writing, the acrimonious departure of Prof. Richard Tol from the Economic and Social Research Institute has led to a very public exchange between its researchers as to the extent of its independence from state prerogatives and political pressure (see Keena, 2012).

8. See, for example, the New York Times investigation of insurance fraud (Lavery and O'Brien, 2005) and the Guardian investigation of UK firms using Irish 'brassplates' for tax purposes (Tax Gap, 2009).

9. Ahern's 'suicide' quip was mentioned as an example of this pressure, see Note 7.

10. The call for involvement put it this way: 'Please read, comment link and tweet, but better still get involved. We are not looking for political or ideological unity. The only thing we are looking for is cold rage put to good use, and that you never believed in David McWilliams 'wonder bra ' theory of the economy.' (McWilliams is a popular economist whose 2005 book The Pope's Children presented a taxonomy of new social 'types' in Ireland, closely modeled on David Brooks' 2000 book Bobos in Paradise).

11. There is significant disagreement between political economists as to the utility of 'neoliberalism' as a conceptual framework for analysing the historical development of the economy in Ireland. See McCabe (2011) for commentary.

12. For a discussion of neoliberal discourse as a 'contaminable construction' see Fairclough (2003) Analysing Discourse: Textual Analysis for Social Research.

13. The project is archived at http:/www.politico.ie/index.php?option=com_magazine\&func= show edition \&id $=398$

14. (As yet) unpublished research interview, 27 August 2011.

15. See Note 5 above.

16. The Story ie is a blog dedicated to 'transparency in public life'. In 2011, it succeeded in having NAMA declared a public authority, with obvious ramifications for what can be 
requested under Freedom of Information legislation. See http:/thestory.ie/2010/07/27/ is-nama-a-public-authority/

17. See for example, how a piece by the chief polit ical correspondent of the Irish Times, Stephen Collins (2012), that argues that a potential 'no' vote on an EU treaty implementing a fiscal compact would inevitably result in Ireland leaving the Eurozone, is factually examined on the blog, O’Broin (2012).

18. Thanks to Rosi Braidotti for discussing this point.

19. In translating Budgetiam into a more stable collective, Crisisiam, we attempted to keep the focus on neoliberal rationality and the crisis, and to structure our productions around countervailing readings of key events; the 2011 general election; International Women's Day and the disproportionate impacts of austerity politics on working-class women; the visit of Queen Elizabeth to Ireland; an internationalist analysis involving ZNet, New Left Project and others to mark May Day. The May Day International project and ebook, featuring research and writing from the USA, UK, Ireland, Portugal, Spain and Greece can be found at http://www.newleftproject.org/index.php/mayday and see also Douzinas et al. (2011). However, ultimately Crisisjam settled down into a conventional blog/online form magazine, one that maintains a dedicated if modest readership, an interesting and diverse network of writers, and participates in networking content with colleagues in the UK, Europe and North America.

\section{References}

Badiou A (2010) The Communist Hypothesis. London: Verso.

Brady C (2010) Did the media fail to sound the alarm bells before the crisis? The Irish Times, 6 March.

Brown W (2005) Neoliberalism and the end of liberal democracy. Edgework: Critical Essays on Knowledge and Politics. Princeton, NJ: Princeton University Press.

Burke M (2011) Corporation tax cuts don't lead to prosperity. Socialist Economic Bulletin, 23 January. Available at: http://socialisteconomicbulletin.blogspot.com/2011/01/corporation-taxcuts-dont-lead-to_23.html (accessed 18 December 2011).

Collins S (2012) Year ahead could be as politically dramatic as the last. The Irish Times, 31 December.

Couldry N (2010) Why Voice Matters: Culture and Politics after Neoliberalism. London: Sage.

Crouch C (2011) The Strange Non-Death of Neoliberalism. Cambridge: Polity Press.

Dean J (2009) Democracy and Other Neoliberal Fantasies. Durham, NC: Duke University Press.

Douzinas C, Titley G and Wearing D (2011) Austerity? There is an alternative. A new project for Europe's left. The Guardian, Comment is Free, 1 May.

Ehrenreich B (2009) Smile or Die: How Positive Thinking Fooled America and the World. London: Granta.

Elliot L (2010) Ireland's austerity measures show us not how to do it. The Guardian, 23 September. Fahy D, O'Brien M and Poti V (2010) Combative critics or captured collaborators? Irish financial journalism and the end of the Celtic Tiger. Irish Communications Review 12: 5-20.

Fairclough N (2003) Analysing Discourse: Textual Analysis for Social Research. London: Sage. Finn D (2011) Ireland on the turn? Political and economic consequences of the crash. New Left Review 67 (Jan-Feb): 5-39.

Gaffney M (2007) What's the craic? Irish Times Magazine, 10 March.

Graeber D (2011a) Debt: The First 5,000 Years. New York: Melville House. 
Graeber D (2011b) Occupy and anarchism's gift of democracy. The Guardian, Comment is Free, 15 November. Available at: http://www.guardian.co.uk/commentisfree/cifamerica/2011/ nov/15/occupy-anarchism-gift-democracy (accessed 5 January 2012).

Hind D (2010) The Return of the Public. London: Verso.

Keena C (2012) Economist criticizes aspects of ESRI. The Irish Times, 2 January.

Kinsella S (2011) What the EU should learn from Ireland's austerity fiasco. Foreign Affairs, 13 December. Available at: http:/www.foreignaffairs.com/features/letters-from/what-the-eushould-learn-from-irelands-austerity-fiasco (accessed 18 December 2011).

Kirby P, Cronin M and Gibbons L (2002) Reinventing Ireland: Culture and the Celtic Tiger. London: Pluto.

Larragy J (2006) Origins and significance of the community and voluntary pillar in Irish social partnership. Economic and Social Review 37(3): 375-398.

Lash S (2007) Power after hegemony? Cultural studies in mutation? Theory, Culture \& Society 24(3): 55-78.

Lavery B and O'Brien TL (2005) For insurance regulators, trails lead to Dublin. New York Times, 1 April. Available at: http://www.nytimes.com/2005/04/01/business/worldbusiness/01 irish. html (accessed 12 January 2012).

Lewis M (2011) When Irish eyes are crying. Vanity Fair, March.

Lievrouw L (2011) Alternative and Activist New Media. Cambridge: Polity Press.

Louw E (2005) The Media and Political Process. London: Sage.

McCabe C (2011) The Sins of the Fathers: Tracing the Decisions that Shaped the Irish Economy. Dublin: History Press.

McNally D (2011) Global Slump: The Economics and Politics of Crisis and Resistance. Oakland, CA: PM Press.

O'Brennan J and Titley G (2011) Ireland has done what the IMF asked, so where's the reward? The Guardian, Comment is Free, 29 December. Available at: http://www.guardian.co.uk/ commentisfree/2011/dec/29/ireland-imf-reward (accessed 5 January 2012).

O'Broin E (2012) Stephen Collins bothers me. Available at: http://eoinobroin.wordpress. com/2012/01/03/stephen-collins-bothers-me/

O'Hearn D (2011) What happened to the Celtic Tiger? Translocations: Migration and Social Change $7(1)$.

Peck J (2011) Constructions of Neoliberal Rationality. Oxford: Oxford University Press.

Poole S (2011) Austerity measures: Enhancing the credibility deficit. Unspeak. Available at: http://unspeak.net/austerity-measures/

Russell A (2011) Networked: A Contemporary History of News in Transition. Cambridge: Polity Press.

SchechterD(2012) Want tounderstand theeconomy? Don 'tread thepress. AlJazeeraonline, 13 January. Available at: http://www.aljazeera.com/indepth/opinion/2012/01/2012111124839271411. html (accessed 14 January 2012).

Slattery L (2010) Banking crisis: How the costs have evolved. The Irish Times, 1 October.

Storey A (2010) IMF history - what did happen in South Korea? Available at: http://www.politico. ie/the-imf/6942-imf-history-what-happened-in-south-korea.html

Tambini D (2008) What Is Financial Journalism for? Ethics and Responsibility in a Time of Crisis and Change. London: Polis, London School of Economics and Political Science.

Tambini D (2010) What are financial journalists for? Journalism Studies 11(2): 158-174.

Tax Gap Reporting Team (2009) Low-tax, low-cost flight to Dublin. The Guardian, 10 February. Available at: http:/www.guardian. co.uk/business/2009/feb/10/ireland-tax-gap-staff-levels (accessed 8 January 2012). 
Witschge T, Fenton N and Freedman D (2010) Protecting the News: Civil Society and the Media. London: Carnegie UK.

\section{Author biography}

Gavan Titley is Lecturer in Media Studies in the National University of Ireland, Maynooth. His most recent publication is The Crises of Multiculturalism: Racism in a Neoliberal Age (with Alana Lentin, Zed Books, 2011). 